\title{
Research on Professional Ethics of Accountants in New Times
}

\author{
Hao $\mathrm{Xu}^{1, \mathrm{a}}$, * Sen Wang ${ }^{1, \mathrm{~b}}$ \\ ${ }^{1}$ College of Applied Science and technology, Hainan University, Danzhou, Hainan, China, 571737 \\ ${ }^{*}$ Corresponding Author: Hao Xu \\ ${ }^{a}$ email, ${ }^{b}$ email
}

Keywords: Accountants, Professional ethics, Accounting integrity

\begin{abstract}
Accounting professional ethics is the common requirement of the society for the accounting professional behaviors. Accounting professional ethics plays an important role in the enterprise operation process. However, in the new times, the professional ethics of the accounting personnel in our country is facing many challenges. There are also some problems in the professional ethics, such as inadequate education, incomplete institutions and low legislation enforcement. This paper analyzes these problems and gives the corresponding countermeasures to provide some references for the relative researchers.
\end{abstract}

\section{Concept of Accounting Professional Ethics}

Ethics is the standard of the social behaviors of members in a society. It represents the desire and will of the public. The accounting occupation ethics is the common will bill of the accounting personnel behavior which requires accountants follow in accounting occupation activities. Like the ethics, the accounting professional ethics is the common requirement for the accounting professional behavior. With the deepening of the reform of the enterprise property right system, accounting not only provide the accounting information to meet the requirements of government agencies, corporate management, but also for the investors, creditors and employees involved in services, accounting behavior is the national and public interests. Accounting is a very practical economic discipline, which is to strengthen management and improve economic efficiency. Any society and individuals are not contrary to the objective economic law. The confirmation, measurement, record and report of accounting unit of economic operations, accounting standard design, accounting policies, accounting methods in the market must follow the objective economic law.

\section{Challenges of Professional Ethics of Accountants in New Times}

The transformation of China's economic system is a profound social change, which not only provides opportunities for the sustainable development of society, but also creates conditions for the social accounting professional ethics decline. With the development of the reform and opening up, the reform of the accounting profession has made some achievements. With the development of society and progress, some of the old accounting standards for the accounting personnel have lost the binding force, greatly reducing the authority of the accounting professional ethics. In the process of China's economic development, there has been a large scale of accounting information is not true, which is the biggest problem in the construction of the accounting profession in the construction of professional ethics. In the new period, the time period between the financial crisis and the global economic recovery is the time when the financial crisis began to affect the international financial 
crisis. The root cause of the crisis is not possible or not completely gets rid of the economic and financial aspects. There is still a lot of uncertainty and instability. The new period is still in an overall easing and unknown turbulence state. Accounting personnel should love their own work, and strive to study business, so that their knowledge and skills to adapt to the requirements of the work. Dedication is the starting point of all the work of the. Accounting personnel should be familiar with the financial laws and regulations and the national unified accounting system, do their business in handling the economic law in accordance with the law, and also carry out the regulations of publicity, improve the legal system. Whether the accounting information is correct or not is not only related to the micro decision, but also related to the macro - decision - making. Do a good job in accounting, not only to have excellent technical skills, but also requires the spirit of seeking truth from facts and objective and impartial attitude. Otherwise, will put knowledge and skills in the wrong place, or even participate in resort to deceit. The new era of the economic outlook is very vague, leading to all kinds of capital is not willing to invest in the real economy in the longer period, but also changed the survival and development of small and medium-sized enterprise environment, causes the enterprise financing channel is not smooth, cash flow difficulties, leading to the development of efficiency is not high, profit margins shrink. Enterprise assets shrinking may cover up some of the substantial loss in the annual report.

\section{Problems of Professional Ethics of Accountants in New Times}

Inadequate Education of Professional Ethics. At present, the majority of our financial personnel lack the necessary understanding of accounting occupation morals. They don't want to learn to update the new financial regulations, national tax policy, one-sided financial work and accounting records. The go-slow work attitude and lack of occupation ideal and professionalism of financial work are very common. Accounting information distortion is that the accounting information does not reflect the real and objective economic activities, thus providing false information to the users of the accounting information. Accounting information distortion is a universal problem. Now the development momentum in recent years, the accounting personnel occupation moral anomie is relatively common, outstanding performance for the serious distortion of accounting information, accounting prevalent. The accounting system has been gradually in line with international accounting standards in China, but in the construction of professional ethics of accounting practitioners, it is backward in the western advanced countries. The accounting education in our country has mostly focused on the accounting theory and business operations, and ignored the accounting professional ethics education. Some training institutions and even unscrupulous teach students how to cook the books and how to escape inspection which are obviously contrary to the accounting occupation ethics.

Incomplete Institutions of Enterprises' Accounting. From the perspective of the enterprise, the working attitude of most accounting practitioners is not correct. They often lack the responsibility. It is more prominent in the state-owned enterprise or business unit performance. Some accounting personnel lack of development vision, too much emphasis on the immediate interests, the proportion of the cost of human control income, serious violation of the relevant provisions of the accounting standards. In addition, the internal supervision and control mechanism is not perfect. Some enterprises in order to achieve tax evasion, listed companies to issue stock standards and disclosure annual financial statements, the assets of financial institutions loan audit, enterprise financial staffing false financial information, financial personnel selection between occupation morality and leadership pressure to keep their jobs. Although there are many relevant supervising departments, but due to inadequate supervision, the phenomenon of making fake 
accounting is frequent. Accounting personnel's own legal consciousness is weak and the business level is not high. With the continuous improvement in people's income level, the price rise, the basic wage has been unable to meet the needs of people with high levels of life, which leads to the accounting personnel to appear money worship, embezzlement, forgery of accounting data, is not conducive to the rapid development of enterprises.

Low Punishment of Relative Laws. The system of accounting ethics construction in the enterprise interior perfection will affect the accounting management of the enterprise accounting system, the implementation will be due to many reasons did not execute in place, the system and the system useless, or is only in the initial stressed that implementation of the system, emphasizing the moral construction, a long time will put any of these. Will lead to violations of the. Therefore, to reduce and eliminate the illegal behavior of accounting personnel, improve the accounting system and system, and create a good social atmosphere is the important reason for the current accounting personnel to strengthen the construction of accounting professional ethics. Although China has promulgated the accounting law corresponding Tianjin regulations, however, in the actual work process, enforcement is weak. In the process of accounting laws and regulations construction, supervision and management mechanism is not perfect, the internal audit department is only the form of existence, cannot effectively play the function of supervision and management. From a practical point of view, a large number of accounting laws and regulations cannot be effectively implemented. Knowing illegal phenomenon still exists in some extent. The implementation of various regulatory systems lacks of the necessary inspection and supervision. Internal audit in some units is completely formalism. It does not play the role of supervision.

\section{Corresponding Measures of Professional Ethics of Accountants in New Times}

Strengthen Education of Professional Ethics. The vocational moral education can be implemented by external and internal education. External education refers to the accounting personnel occupation responsibility, positive to the occupation duty as the core content of Indoctrination through school or training institutions, to standardize the occupation behavior, safeguard national and social public interests in education. Inner education is a kind of behavior activity of self - learning and self - moral cultivation. Through the self-education, and in practice, to promote and guide the accounting personnel to self-education, can gradually develop good moral behavior, and thus achieve the sublimation of the moral realm. Through the study of accounting occupation moral knowledge, establish the accounting occupation moral concept, to understand the impact of accounting occupation morals on social and economic order, the quality of accounting information, and the violation of accounting occupation moral will be subject to disciplinary punishment and liu. The professional ethics education mechanism of accounting personnel in our country is far behind the western developed countries. While the occupation moral education is to cultivate personnel occupation ethics, accounting personnel only knowing the law to be law-abiding. The accounting occupation moral warning education by means of a violation of accounting occupation moral behavior and typical cases are discussed and analyzed in violation of accounting behavior, get the warning, the ability to raise awareness of the law, the accounting occupation morals and righteousness. Therefore, at this stage, we should build a complete professional ethics education system as one of the important ways to improve the professional ethics of accounting practitioners. It is necessary to improve the professional ethics of accounting practitioners in our country, a variety of methods of education system, can be carried out free education and training, screening does not meet the requirements of training institutions and other ways to carry out. At the 
same time, it is also needed to strengthen the identification of accounting practitioners for the existence of economic stain on the personnel to engage in accounting work.

Improve Institutions of Enterprises' Accounting. The internal control system of enterprise employees of various departments within the different specific management control methods. Only to establish a reasonable system of internal control can be effective for enterprise managers, financial and accounting personnel to regulate and supervise and control. Some enterprises through the establishment of accounting rotation system reduces the appearance of corruption, while the rotation system can also enhance the internal accounting supervision of enterprise accounting personnel, reduce the occurrence of corruption. The perfect internal control system can also be "kill" the problem in the bud, discover the enterprise accounting appears against the occupation moral problems and resolved in a timely manner, and effectively reduce the long-term accounting irregularities phenomenon. Enterprises should establish an independent internal audit institution to ensure that it can be fair and independent of the internal audit business. At the same time, strengthen the coordination of the business department of internal audit, the audit found irregularities in the serious rectification, and constantly improve the quality of accounting information and the implementation of internal control effect. Financial officers in the same position for a long time will be to provide the soil for financial personnel corruption, but also not conducive to the timely detection of economic activity in the presence of illegal problems. Enterprises should establish a financial system in the internal job rotation, as well as strengthening internal supervision of enterprise, but also in the internal effective containment formed by post-handover inventory, in order to reduce the risk of the individual financial personnel corruption and embezzlement are not found.

Increase Enforcement of Legal Regulations. The economic crime cost is low in our country and the supervision of accounting behavior is weak. Therefore, only by strengthening the law in the construction of accounting professional ethics, can we have a deterrent effect on the accounting professionals who are in violation of the accounting professional ethics. Establish a sound legal system, increase the intensity of supervision, will also promote enterprise accounting personnel independent study of accounting professional ethics. The actual purpose of this measure is to improve the cost of illegal accounting and law risk, let the accounting staff have fear, only to abide by the accounting regulations, occupation moral caution, it does not appear that may be too late to regret. Current accounting fraud repeated, fundamentally speaking, the accounting fraud is driven by interests, is the result of poor cost of income. When the income of accounting fraud is greater than the cost of accounting fraud, it will induce the behavior of accounting fraud. Therefore, the irregularities punishment must be made clear, by increasing the penalties for wrong or guilty of managers, so as to form the self-constraint of the management of the company. At the same time, the law of our country can establish responsibility of compensation system, namely the accounting personnel need to because of their own negligence or intentionally caused economic losses to the compensation, which will greatly reduce the accounting personnel responsibility caused by the lack of economic losses. To carry out the accounting occupation moral construction needs the concerted efforts of the whole society, cooperation, supervision, to play the role of organizations at all levels, all levels of government, the masses and the media, to promote righteousness, to combat unhealthy practices, the formation of the whole society are concerned about the occupation moral construction atmosphere. According to the accounting occupation morals behavior should be rewarded for moral turpitude. The accounting personnel who take advantage of his position to accept bribes should be severely punished. 


\section{Conclusion}

By analyzing how to strengthen the construction of accounting professional ethics in the new times, we can see that the important role of the accounting professional ethics in the development of enterprises. However, affected by various factors, there are various defects and problems in the process of the construction of the accounting professional ethics. Therefore, at this stage, the enterprise management personnel should be aware of the importance of the construction of professional ethics to ensure the authenticity of accounting information. Only in this way, we can have a solid foundation for the right decision of the enterprise.

\section{References}

[1] Jian Feifan, Market Modernization, Vol. 44 (2015) No 1, p. 169-171

[2] Han Min, China Management Informationization, Vol. 14 (2011) No 2, p. 14-17

[3] Cao Shuai, Times Finance, Vol. 37 (2016) No 6, p. 169-170

[4] Jiang Nan, China Township Enterprises Accounting, Vol. 23 (2015) No 1, p. 180-181 